\title{
Examining sensory differences of children with autism in early childhood: Effects of school and home settings
}

\begin{abstract}
Alev Girli ${ }^{1}$
Abstract

Recently, towards stimuli giving over sensitive or insensitive reactions has been recognized as diagnostic distinctive characteristics in children with autism. One of the purposes of this study is to determine behaviors which behaviors are result of sensitivity, prevalence rate at home or school settings and types of occurrence seen by parents and teachers. Another purpose of this study is to examine parent and teacher views on sensitivity effects at school and home settings. Study group consist 22 children with autism (2-6 ages), 20 mothers, and 8 trainers (4 psychologists and 4 special education teachers) who work with those children. In order to collect types of sensitivity and prevalence rate, "Sensory Difference Observation Form" and in order to collect views of parents and teachers, a semi structured form, "Effects of Sensory Differences: Parent and Teacher Views Form" are used. Forms were designed by researcher. It has been determined that the insensitivity of children towards movement, touch as well as auditory, visual and taste-scent stimuli is more common with a higher ratio than sensitivity. It has been observed that these properties have negative effects on their home lives as well as the routines of families and that teachers cope with them more easily in school settings.
\end{abstract}

Keywords: Autism; early childhood; sensory differences; parent views; teacher views.

\section{Introduction}

Sensory differences first observed by Kanner (1943) and Asperger (1944) have started to be accepted as a signifying property for children in autism spectrum disorder (ASD) group (Klintwall et.al., 2011). Studies indicate that children with autism have sensory differences (Ben-Sasson, Hen, Fluss, Cermak, Engel-Yeger \& Gal, 2008). The over sensitive or insensitive reactions of children with autism against stimuli have recently been started to be recognized/accepted as diagnostic differentials (see www.dsm5.org, for details).

According to Dunn (1997), some children with autism are less sensitive to movement, vestibular, auditory, visual, taste and scent stimuli and demand them more whereas some are over sensitive and try to refrain from them (Smith-Myles, Tapscott-Cook, Miller, Rinner \& Robbins, 2000). For example, if a child is overly sensitive to auditory stimuli, he/she can shut his/her ears with his/her hands upon hearing music or talks/gives verbal reactions with a very low tone of voice. Children who are over sensitive to movement refrain from climbing down the stairs, sliding, swinging whereas those who are insensitive move aimlessly running around, jumping and swinging. Children who are over sensitive to touch refrain from holding various materials, for example plastic

\footnotetext{
1 Ass. Prof., Dokuz Eylül University, Buca Faculty of Education, Department of Special Education,
} alev.girli@deu.edu.tr 
Girli, A. (2016). Examining sensory differences of children with autism in early childhood: Effects of school and home settings. International Journal of Human Sciences, 13(1), 518-531. doi:10.14687/ijhs.v13i1.3520

materials, play dough or plush toys (Tomchek and Dunn, 2007; Rogers, Hepburn \& Wehner, 2003). The personal accounts of some adult autistic individuals as well as study results have shown that they may refrain violently from activities such as wearing knit/wool clothes, cutting nails, washing face, cutting hair or various other personal care activities (Fazloğlu 2004; Grandin, 1996; Kientz and Dunn 1997; Korkmaz, 2003).

It is known that even though children with autism cannot look at the faces of people and many of the objects around them, they can look at some bright objects for a long time. It is observed that some of them are sometimes disturbed by light and that they are more comfortable in a dark room. It has been stated that there are some children with autism who close their eyes when faced with light. Problems related with visual sensitivity in children with autism can be in the form of weak eye contact, squinting, winking and being disturbed by light (McConachie and Moore 1992, Wainwright-Sharp and Brayson 1996, Case-Smith and Miller 1999).

Rogers et.al. (2003) have applied a form informing about their sensory abilities to the families of children with autism in order to determine their sensory responses. 102 children with autism, Fragile X syndrome as well as those displaying normal development and those for whom development retardation has been determined at an average age of 22 months have been included in the study. These four groups of children have been found to be different in terms of their sensitivities of touch, taste and scent. It has been determined that especially taste and scent senses of children with autism are more problematic than all. Leekam, Nieto, Libby, Wing, Gould (2007), have carried out a study comparing the speech insufficiency of children with autism with the group having development retardation as a result of which they have determined that the sensory anomalies of children with autism are greater in ratio $(90 \%)$ and that it is observed more commonly in many areas. A study carried out in Australia has compared 27 children with autism with 30 normally developing children between the ages of 4-14 determining a statistically significant difference between the two groups in all sensory areas (Talay-Ongun and Wood, 2000). Dunn, Myles and Orr (2002a) have compared children with Asperger syndrome diagnosis with children displaying typical development using Dunn's (1999) "Sensory Profile" scale determining that $96 \%$ had differences.

It has been determined in a meta-analysis evaluating the studies carried out between 19982007 that children in the autism spectrum group have significantly less sensory responses in comparison with children displaying typical development (Ben-Sasson et.al., 2008). Chronological age, the level of insufficiency and cognitive level are put forth as factors affecting sensory differences of children with autism in various studies (Ben-Sasson, et.al., 2008). Whereas it is expressed in some studies that cognitive level and expressive language skill level are not important in the number of sensory differences (Rogers, Hepburn \& Wehner, 2003; Klintwall et.al., 2011). It is emphasized by various researchers that sensory processing problems are observed intensively in children with autism and that these problems start during infancy which then continue during the childhood and adolescent years after which they decrease in adulthood (Baranek, David, Poe, Stone, \& Watson, 2006 ; Dawson and Watling 2000; Leekam et.al., 2007 ). Militerni et.al. (2002) have examined the relationship between repetitive behavior in one hundred and twenty one children with autism with ages ranging between two-four and seven-eleven and developmental level, chronological age, mood, intensity of the sickness, reaction against environmental stimuli. They have reported as a result of this study that motor and sensory repetitive behavior have been observed more in small children with autism, whereas more complex repetitive behavior have been observed in older children. In addition, it has also been determined that there is an increase in the complex repetitive behavior as the IQ levels of the children increase. Minshew and Hobson (2008) have carried out a study during which they have compared 60 children, adults and adolescents with high functions with a 61 people control group displaying typical development in terms of their age, intelligence and the socio-economic levels of their families finding differences between groups in terms of sensory sensitivities in every age groups. No difference was determined in terms of age and intelligence (IQ between 90-145 ages between 8-54) in the individuals of the ASD group. It is 
Girli, A. (2016). Examining sensory differences of children with autism in early childhood: Effects of school and home settings. International Journal of Human Sciences, 13(1), 518-531. doi:10.14687/ijhs.v13i1.3520

not clear enough whether there is a relationship between sensory differences and chronological age, intelligence age and ASD sub-types due to the contradictory results.

It is stated that the differences arising from sensory differences affect the participation of children with autism in games, social activities, self care and learning process and that the families are affected by this (Baranek, 2002; Leekam et.al., 2007; Rogers \& Ozonoff, 2005). It has been observed that the behavior of children with autism regarding their sensory differences is among the problems most often reported by families during the treatment/training stage (Mandell et.al., 2005; Green et.al., 2006). It has been determined that the behaviors arising from the sensory differences of children also affect the work, family and leisure times of the family (Schaaf, Toth-Cohen, Johnson and Benevides, 2011) and that families can manage daily routines using specific strategies.

Sensory differences in children can also cause problems in their school lives. For example, Ashburner, Ziviani, and Rodger (2008) have put forth in their studies the auditory sensitivity and emotional search of children with ASD between the ages of 6-10 contribute to their academic failure and that tactual and auditory sensitivities decrease class performance. Being aware of the senses that children with autism refrain from or prefer may guide the families to understand their behavior better and also educators in determining where to start communicating with them. Defining the sensory preferences of the child may enable us to understand with what kind of activities they are motivated easily or with what kind of activities they can learn easily. The child will be able focus more and learn more easily when he/she prefers to use the senses with which they prefer (Sussman, 1999).

The number of studies in Turkey carried out on the sensory differences of children with autism is very limited. The study carried out by Fazlıoğlu (2004) has put forth the sensory differences between 30 children with autism with ages ranging between seven-eleven who have been diagnosed according to DSM-IV criteria and a sensory integration program has been applied on the experiment group. It has been determined as a result of the study that sensory integration program is effective on the sensory and behavioral problems of children with autism. Whereas the sensory differences of 19 children diagnosed with autism according to DSM-IV criteria with ages ranging between 7 and 21 have been evaluated in the study of Ersöz (2006) and an art program of three months has been applied to ten children in the experimental group. A decrease has been observed in the sensory problems of children with autism in the experimental group while no statistically significant change has been observed in the sensory problems of children with autism in the control group.

One of the objectives of this study is to determine the prevalence of behavior in children with autism resulting due to sensory differences observed by families and teachers in various environments such as home, education environment as well as their ways of appearance. Another objective is to examine the opinions of families and teachers regarding the effects of these sensory differences to the home and school environments.

\section{Method}

This research is a descriptive study. The research model which is one of the qualitative research methods. In qualitative research data collection is done via qualitative data collection techniques such as observation, interview and document analyses and it is also a qualitative process in which perceptions and events take place in their natural environment and in a comprehensive way (Ylldirm \& Simsek, 2000). The data was collected through semi-structured interview technique and observation form.

\subsection{Participants}

The participants were determined by using purposeful sampling method. The family and trainer participants of the study consisted of volunteer mothers and instructors from among those who attended the "Autism and Sensory Differences" conference by the researcher whose children with autism meet the below pre-conditions The pre-conditions determined for children with 
Girli, A. (2016). Examining sensory differences of children with autism in early childhood: Effects of school and home settings. International Journal of Human Sciences, 13(1), 518-531. doi:10.14687/ijhs.v13i1.3520

autism, a) that the autism diagnosis of their children should have been given by an expert team in the child psychiatry departments of university hospitals including a child psychiatrist and clinical psychologist meeting DSM-IV and ICD-10 diagnosis criteria, b) that the ages of the children are between 2-6 years. The study group consisted of 22 children who met these criteria, their 20 mothers and 8 trainers.

2 of the children were female and 20 were male with an age range of between 29- 66 months. 11 children $(50 \%)$ did not have any siblings, whereas $11(50 \%)$ had one. Of these siblings 3 display autistic development $(33 \%)$ whereas $8(67 \%)$ display normal development. The socio economic levels of the families are moderate. All the mothers who participated in the study were housewives. Their ages varied between 23-38 mounts. Four special instructors and four psychologists who were the trainers of these children were also included in the study as participants. The ages of the instructors varied between 23- 35 years and they were all female. The trainers had an experience of 2-8 years of working with children with autism.

\subsection{Data Acquisition Tools}

"Sensory Differences Observation Form" has been used to determine the personal information of the children as well as their sensory differences. Two semi-structured interview forms with the names of "Family Interview Form" and "Trainers Interview Form" have been used to determine the personal information of the families and teachers as well as their opinions regarding "the effects of the sensory differences of children with autism on the home and education environments".

Sensory Differences Observation Form: The form has been prepared by the researchers following a survey of relevant literature. The form consists of a total of 60 behaviors putting forth sensory differences that can be broken down as 10 for hearing/auditory, 10 for seeing, 16 for touching, 19 for movement and 5 for taste and scent. The form has been arranged so that the observers can mark the behavior they observed in the children and write down several example observations.

Interview Forms: These forms have been prepared by the researchers following a survey of relevant literature. The Family Interview Form consists of semi-structured nine questions to determine the effects of the sensory differences of the children on the home environment as well as five questions to determine the personal information of the parents for a total of fourteen questions. The Trainer Interview Form consists of four questions including the personal information of children and five questions prepared to determine the effects of the sensory differences of the children on the education environment for a total of nine questions.

\subsection{Procedure}

Observation form was given to the volunteer participant mothers and trainers at the end of the conference given by the researcher and how to fill the form was also explained. The researcher has made an explanation to the mothers as such, "record the behavior you observe in your children at home in the appropriate section, if there are those which you have difficulty to place under a specific heading, write these behind the form in detail". The same explanation was written for the trainers as, "“record the behavior you observe in your children at school in the appropriate section, if there are those which you have difficulty to place under a specific heading, write these behind the form in detail". The observation forms were collected one week later when the institutions were visited. The one-to-one interviews with the mothers and trainers were carried out individually at the special education centers to which the children attend and each interview lasted for 30-35 minutes. Real names of the mothers and trainers were used during the interviews. However, a code was given to each participant during data analysis. Accordingly, children were coded as C1.....C22, mothers as M1....M4 and trainers as T1....T4. 
Girli, A. (2016). Examining sensory differences of children with autism in early childhood: Effects of school and home settings. International Journal of Human Sciences, 13(1), 518-531. doi:10.14687/ijhs.v13i1.3520

\subsection{Data Analysis}

The frequencies and percentages of the behavior specified by mothers and instructors in the Sensory Differences Observation Form were calculated. It was observed that many behaviors were explained in detail with examples under the observation form without placing them under a specific heading. The written examples have been examined and distributed according to the relevant areas. The percentage and frequency distributions along with the data for values or scores were based on one or more subjects in order to determine the distribution properties. Percentage and Frequency distributions are the most commonly used statistical methods in qualitative studies such as this one where the number of participants is low (Büyüköztürk, 2003).

The records of the interviews carried out to collect data regarding the effects of sensory differences on the family and education lives have been analyzed via content analysis method. The main objective here was to reach the concepts and relations that can explain the acquired data. Similar data put forth by the mothers and instructors were brought together around various concepts and themes. These responses have been interpreted within the framework of these themes.

\subsection{Reliability}

The data collected from the records of mothers and instructors were used to calculate the reliability among observers using the formula "agreement of opinion/agreement of opinion + difference of opinion x 100" in order to provide reliability among observers regarding sensory differences. (Kurcaali-İftar and Tekin, 1997). It was observed that the reliability coefficients varied between $80 \%$ and $100 \%$.

\section{Results}

First, the most and least frequent sensory differences observed in the children by their mothers and trainers were tabulated by grouping them according to their respective sensitivity areas and some of the examples given have been presented. Afterwards, analyses were made regarding the effects of these properties on the home and school environments.

\section{Table 1. Movement Related Sensory Differences Observed in Children with Autism}

\begin{tabular}{|c|c|c|c|c|c|}
\hline \multirow[b]{2}{*}{ Most Frequent } & \multicolumn{2}{|c|}{$\begin{array}{c}\text { Trainers } \\
\text { Observations }\end{array}$} & \multicolumn{2}{|c|}{$\begin{array}{c}\text { Mother } \\
\text { Observations }\end{array}$} & \multirow[t]{2}{*}{ Observation examples } \\
\hline & $\mathbf{N}$ & $\%$ & $\mathbf{N}$ & $\%$ & \\
\hline Does not use toys properly & 18 & 81,82 & 16 & 72,73 & \multirow{7}{*}{$\begin{array}{l}\text { T2: "My student (C1) almost never } \\
\text { sat down when we first started } \\
\text { education, he either walked or ran } \\
\text { aimlessly, took a material and either } \\
\text { shook it or banged it around" } \\
\text { M4: "My son (C5) either rocks back } \\
\text { and forth or shakes an object when } \\
\text { I do not interfere" }\end{array}$} \\
\hline Rocks back and forth & 16 & 72,73 & 15 & 68,18 & \\
\hline Likes jumping & 15 & 68,18 & 15 & 68,18 & \\
\hline Runs around aimlessly & 13 & 59,09 & 12 & 54,55 & \\
\hline Walks around aimlessly & 12 & 54,55 & 9 & 40,91 & \\
\hline $\begin{array}{l}\text { Plays with the same toy for a long } \\
\text { time }\end{array}$ & 11 & 50,00 & 10 & 45,45 & \\
\hline $\begin{array}{l}\text { Plays games without rules } \\
\text { Least Frequent }\end{array}$ & 12 & 54,55 & 12 & 54,55 & \\
\hline Scared of steps or escalators & 1 & 4,55 & 1 & 4,55 & \multirow{3}{*}{$\begin{array}{l}\text { M7: "(C10) shouts out oud } \\
\text { whenever we come near an escalator } \\
\text { in a shopping mall, it was only much } \\
\text { later that we understood he was } \\
\text { afraid of stairs". Trainer T3: "My } \\
\text { student (C14) reacts against active } \\
\text { games, he always insists on sitting } \\
\text { down to study" }\end{array}$} \\
\hline $\begin{array}{l}\text { Does not like playing active } \\
\text { games }\end{array}$ & 2 & 9,09 & 2 & 9,09 & \\
\hline $\begin{array}{l}\text { Scared of swings, slides and teeter } \\
\text { totters }\end{array}$ & 2 & 9,09 & 3 & 13,64 & \\
\hline
\end{tabular}


Girli, A. (2016). Examining sensory differences of children with autism in early childhood: Effects of school and home settings. International Journal of Human Sciences, 13(1), 518-531. doi:10.14687/ijhs.v13i1.3520

As can be seen in Table 1, the most frequent among the behaviors that display the sensitivity of the children towards activity are ordering toys, rocking back and forth and jumping both at home and at schools which are due to low sensitivity towards movement. Observations of the mothers are similar to those of the instructors. However, it is observed that the ratios are higher for the school environment.

Whereas it has been observed that children who are excessively sensitive to movement display behaviors such as refraining from steps, being scared of stairs or refraining from games involving activity or moving toys. It was observed that the number of children in the study group that have excessive sensitivities in this regard is lower.

Table 2. Touch Related Sensory Differences Observed in Children with Autism

\begin{tabular}{|c|c|c|c|c|c|}
\hline & \multicolumn{2}{|c|}{$\begin{array}{c}\text { Trainers } \\
\text { Observations }\end{array}$} & \multicolumn{2}{|c|}{$\begin{array}{c}\text { Mother } \\
\text { Observations }\end{array}$} & \multirow[t]{2}{*}{ Observation examples } \\
\hline Most Frequent & $\mathbf{N}$ & $\%$ & $\mathbf{N}$ & $\%$ & \\
\hline Puts objects in mouth & 15 & 68,18 & 13 & 59,09 & \multirow{4}{*}{$\begin{array}{l}\text { M } 5 \text { "My son (C 9) puts whatever } \\
\text { he can get in his hand to his } \\
\text { mouth, he especially likes putting } \\
\text { wooden toys in his mouth" } \\
\text { T5 "(C6) always wants to sit in my } \\
\text { lap, I have difficulty in making } \\
\text { him sit down on a chair" }\end{array}$} \\
\hline Holds objects in hand & 13 & 59,09 & 12 & 54,55 & \\
\hline Gnashes teeth & 10 & 45,45 & 10 & 45,45 & \\
\hline Demands long hugs & 9 & 40,91 & 12 & 54,55 & \\
\hline \multicolumn{6}{|l|}{ Least Frequent } \\
\hline $\begin{array}{l}\text { Likes the fabric of some clothes but } \\
\text { not others }\end{array}$ & 7 & 31,82 & 7 & 31,82 & \multirow{3}{*}{$\begin{array}{l}\text { M } 1 \text { "My daughter (C2) always } \\
\text { wears tights, we can never make } \\
\text { her wear skirts or a sports suit" } \\
\text { T1: "I cannot use playdough with } \\
\text { (C16). He doesn't want to hold } \\
\text { them and it's difficult to move } \\
\text { him to other activities" }\end{array}$} \\
\hline $\begin{array}{l}\text { Does not like sticky things in his } \\
\text { hand }\end{array}$ & 6 & 27,27 & 7 & 31,82 & \\
\hline Insists on wearing tight clothes & 2 & 9,09 & 1 & 8,55 & \\
\hline
\end{tabular}

It has been determined that the number of students that are less sensitive to touch and require more touch related stimuli such as hugging is greater than the number of students who have high sensitivities in this regard and thus who refrain from behavior such as washing hands or wearing certain kinds of cloths. Behavior such as insisting to wear only tight clothes which express a touch related stimulus requirement has been observed only in two children.

Table 3. Sound/Hearing Related Sensory Differences Observed in Children with Autism

\begin{tabular}{|c|c|c|c|c|c|}
\hline & \multicolumn{2}{|c|}{$\begin{array}{c}\text { Trainers } \\
\text { Observations }\end{array}$} & \multicolumn{2}{|c|}{$\begin{array}{c}\text { Mother } \\
\text { Observations }\end{array}$} & \multirow[t]{2}{*}{ Observation examples } \\
\hline Most Frequent & $\mathbf{N}$ & $\%$ & $\mathbf{N}$ & $\%$ & \\
\hline Likes music and certain sounds & 16 & 72,73 & 16 & 72,73 & \multirow{5}{*}{$\begin{array}{l}\text { M3: "(C11) has certain musics } \\
\text { that he likes and is very happy } \\
\text { when he listens to these at every } \\
\text { occasion". } \\
\text { T4: "When I gave directions to } \\
\text { my student (C8), he closed his } \\
\text { ears immediately, I decreased my } \\
\text { tone of voice and now he is more } \\
\text { relaxed and behaves like this less } \\
\text { frequently". }\end{array}$} \\
\hline $\begin{array}{l}\text { Acts as if does not hear what people } \\
\text { say }\end{array}$ & 12 & 54,55 & 12 & 54,55 & \\
\hline Likes toys that make certain sounds & 12 & 50.00 & 12 & 54,55 & \\
\hline Closes his/her ears & 12 & 54,55 & 11 & 50,00 & \\
\hline Likes noisy games/toys & 9 & 40,91 & 10 & 45,45 & \\
\hline \multicolumn{6}{|l|}{ Least Frequent } \\
\hline Talks in a low tone of voice & 4 & 18,18 & 1 & 4,55 & $\begin{array}{l}\text { T5 "My student (C13) talks in } \\
\text { such a low tone of voice that I } \\
\text { can hear him only if I bend down } \\
\text { low towards him" }\end{array}$ \\
\hline
\end{tabular}


Girli, A. (2016). Examining sensory differences of children with autism in early childhood: Effects of school and home settings. International Journal of Human Sciences, 13(1), 518-531. doi:10.14687/ijhs.v13i1.3520

It has been determined that the ratio of children who like music, noisy toys or games with songs; that is children who are less sensitive to sound/aural stimuli is greater than the ratio of children who close their ears not to hear any sound, who speak in low tones of voice and who act as if they do not hear what other people say; that is children who are excessively sensitive towards sound.

Table 4. Visual Sensitivities Observed in Children with Autism

\begin{tabular}{|c|c|c|c|c|c|}
\hline \multirow[b]{2}{*}{ Most Frequent } & \multicolumn{2}{|c|}{$\begin{array}{c}\text { Trainers } \\
\text { Observations }\end{array}$} & \multicolumn{2}{|c|}{$\begin{array}{c}\text { Mother } \\
\text { Observations }\end{array}$} & \multirow[t]{2}{*}{ Observation examples } \\
\hline & $\mathbf{N}$ & $\%$ & $\mathbf{N}$ & $\%$ & \\
\hline Watches moving objects & 17 & 77,27 & 12 & 54,55 & \multirow{4}{*}{$\begin{array}{l}\text { M18: "At first we did not } \\
\text { understand why (C17) kept } \\
\text { looking askew at the television, } \\
\text { but now I have learned that this is } \\
\text { a behavior related with autism." } \\
\text { T7: "(C9) wants to arrange every } \\
\text { material in order or takes them } \\
\text { and looks at them for a long } \\
\text { time." }\end{array}$} \\
\hline Arranges objects in order & 16 & 72,73 & 16 & 72,73 & \\
\hline Watches repetitive movements & 12 & 54,55 & 12 & 54,55 & \\
\hline $\begin{array}{l}\text { Looks at the objects around him } \\
\text { from different angles }\end{array}$ & 9 & 40,91 & 9 & 40,91 & \\
\hline \multicolumn{6}{|l|}{ Least Frequent } \\
\hline Prefers darkness & 1 & 4,55 & 0 & 4.00 & \multirow{4}{*}{$\begin{array}{l}\text { T8 "(C4) squints when the sun } \\
\text { shines in to the classroom; I make } \\
\text { him move to the darker parts of } \\
\text { the classroom when this happens } \\
\text { and I draw the curtains." }\end{array}$} \\
\hline Squints & 2 & 9,09 & 2 & 9,09 & \\
\hline Refrains from sun & 0 & 4.00 & 1 & 4,55 & \\
\hline $\begin{array}{l}\text { Closes his/her eyes with his/her } \\
\text { hands }\end{array}$ & 1 & 4,55 & 3 & 13,64 & \\
\hline
\end{tabular}

As can be seen from Table 4, it has been determined that most of the children are less sensitive in visual field and thus have felt the need of visual stimuli such as arranging objects. Whereas excessive sensitive behavior has been observed in very few children manifesting itself as shutting the eyes with the hands, squinting or preferring dark areas.

Table 5. Scent and Taste Sensitivities Observed in Children with Autism

\begin{tabular}{|c|c|c|c|c|c|}
\hline & \multicolumn{2}{|c|}{$\begin{array}{c}\text { Trainers } \\
\text { Observations }\end{array}$} & \multicolumn{2}{|c|}{$\begin{array}{c}\text { Mother } \\
\text { Observations }\end{array}$} & \multirow[t]{2}{*}{ Observation examples } \\
\hline Most Frequent & $\mathbf{N}$ & $\%$ & $\mathbf{N}$ & $\%$ & \\
\hline $\begin{array}{l}\text { Explores objects by licking or } \\
\text { smelling }\end{array}$ & 16 & 72,73 & 16 & 72,73 & $\begin{array}{l}\text { M20: "My son (C1) eats food that } \\
\text { has been processed by a blender; }\end{array}$ \\
\hline Likes soft food & 9 & 40,91 & 9 & 40,91 & $\begin{array}{l}\text { he wouldn't eat even if there is } \\
\text { the smallest of particles". } \\
\text { T6: "My student (C19) always } \\
\text { smells toys and materials and then } \\
\text { does what is asked" }\end{array}$ \\
\hline \multicolumn{6}{|l|}{ Least Frequent } \\
\hline Is sensitive to certain scents & 3 & 13,64 & 5 & 22,73 & $\begin{array}{l}\text { M19 "My son (C5) smells his } \\
\text { clothes, I realized that he didn't } \\
\text { want to wear them when we } \\
\text { changed the brand of the fabric } \\
\text { softener" }\end{array}$ \\
\hline
\end{tabular}

Most of the children in the study group have displayed less sensitive behavior towards taste and scent such as licking or smelling objects. 
Girli, A. (2016). Examining sensory differences of children with autism in early childhood: Effects of school and home settings. International Journal of Human Sciences, 13(1), 518-531. doi:10.14687/ijhs.v13i1.3520

\section{Effects of Sensory Differences on Home Life:}

When the replies to the eight questions asked to the mothers regarding the effects of sensory differences of children on the family life; it was observed that there are three main themes.

First theme; difficulties arising in the feeding, cleaning, dressing up and other personal care issues.

It has been observed that mothers experience difficulties in feeding and dressing up of their children, the properties of his/her clothes as well as personal care activities and that these difficulties are experienced during every daily routine. It has been observed that the mothers cannot understand the weird behavior of their children with regard to food causing them to feel sad. For example M12 expressed this feeling as such; "my son (C20) eats only the top well cooked parts of the meat ball and leaves the rest. At first this upset my and his father's stomachs and we stopped eating. Now we solved this problem by having him eat first and then eating our own meal afterwards. It's unbelievable but he even eats only the crust of the apple leaving the rest; such behavior makes us feel sad." The child in this example prefers to eat only the crusted parts of foods. However, it is generally reported in literature that eating only the soft parts of foods and rejecting food that should be chewed are observed more frequently.

M1 expresses the difficulty she experiences while dressing up her son with these words: "(C10) does not like hard fabrics and tight clothes such as jeans; he always wants to wear track suits when going out. However sometimes we have to make him wear pants, shirts or sweaters when we are going out for a visit to our friends. He then screams out loud and this has become our nightmare. When we get home he takes off all his clothes and sits naked on the bed."

Whereas M15 says, "(C7) does not like washing his hands, bathing, wearing a cap, combing his hair, having his hair cut and screams most of the time when these happen. However, he started washing his hands at school. But bathing is still a big stress factor for both him and us."

M6 "my son (C 8) does not want his hair to be cut, he reacted greatly the first time we went, that is why we cannot take him to a barber shop now, we cut his hair with my husband." "(C16) resisted a lot to having his hair cut, at first we couldn't get it done, but his teacher at school cut his hair and he didn't reject, now we can also cut his hair at home, this was a very pleasing development for us."

Second Theme; Difficulties caused by the sensory properties of the child at public areas such as shopping malls, parks, public transportation vehicles etc.

Mothers have told that they experience difficulties in public spaces that they are sometimes ashamed and therefore they do not want to go out. For example, M7 "my son (C3) was afraid of getting in the car, we frequently rode in a car when the training sessions started and his fear decreased, but still he is afraid of moving parts such as escalators or lifts and he resists to get on them. This was problematic for us in shopping malls and we solved the problem by going to single floor shopping centers." M17 "(C6) likes hugging a lot, he frequently hugs me and wants to kiss my cheeks, my arms and touch me. This can cause problems in buses, I feel awkward when people start looking at us weirdly." M20 "(C12) eats foods with sharp taste such as sucuk, pickles etc. Of course it's difficult to find the right food when we go to a friend's house or a restaurant; most of the time we give him food that he likes at home prior to going out. This makes us feel sad and of course it is tiring and time consuming, but we do not have strength to try and make him eat other food".

Third Theme; Difficulties caused by the sensory properties of the child at inter familial relations, what do the families do to overcome these problems?

M2 "(C2) continuously runs from one wall to the other in the house shouting iiii along the way and he sometimes scratches the walls with his hands or sometimes licks it. His sister wants to play with him but she cannot succeed because he gets angry and starts crying. Most of the time I have to leave what I am doing and play with him; she cannot understand why his brother does not play with him because she is small. Sometimes she gets jealous and says I will go to private instruction as well. I have to try and balance the two out."

M19 "(C16) wants to wrestle with his dad and play active games such as jumping up and down. But his father is tired when he comes home from work and most of the time he does not want to play. 
Girli, A. (2016). Examining sensory differences of children with autism in early childhood: Effects of school and home settings. International Journal of Human Sciences, 13(1), 518-531. doi:10.14687/ijhs.v13i1.3520

This causes (C16) to get stressed out and start shouting. His father then says that he is disturbed by the shouting. I take (C16) to the kitchen and make him relax with food that he likes. The father can only spend time with (C16) during the weekends. This is very tiring for me, but there is nothing else that we can do. A mother (M3) "my son (C 22) always holds an object in his hand, this was a car once and then we made him forget it but now he walks around with the picture cards he likes."

\section{Effects of Sensory Differences on School Life:}

When the answers given to the five questions asked in order to determine how the sensory differences of children affect the education environment; it was observed that there are three main themes.

First Theme; The effects of the sensory properties of children on education environment and their education works

T1 "it is difficult to carry out desk activities with active children, I first start with activities they like and then I make them sit down even if for a short time and increase the time slowly. These children are also physically tiring." (C2) "The music they like or the visual materials are functional in the beginning to increase communication. However, changing the activity can sometimes cause great resistance. Hence, I think that one should go in stages." T4 "I first had no idea why he cried when he went near the tap, but then I observed his touch sensitivities and then talked with the parents. That is why washing the hands or combing the hair can be a problem in self care activities. We found a bright yellow comb because he likes bright objects and does not reject when we comb his hair with it."

Second Theme; the effects of the sensory differences of the children on group work T3 "I have a student (C7) in my group who is sensitive to touch, and one does not like movement a lot. The one who is sensitive to touch wants to hold hands and rock back and forth like a fisherman but the other does not want to hold hands and just rock back and forth. I first made them hold plastic rings that they like holding and move slowly; now they like the game." T1 "when playing with cars no one wants to drive their car towards another and everybody either watches the wheel or the brand of the car. One to one help is required and most of the time this is tring and difficult. I think it will be difficult to move the attention of the children from objects to their children and make them do something together."

Third Theme; The effects of the sensory properties of children and the resulting behavioral problems on your relationship and the studies carried out by trainers to solve these problems

T2 "I observe that they start crying, shouting or acting angrily when we do not take their emotional preferences into account or when we disregard them and that we cannot overcome these. Or a method that works may not work when tried again. Putting toys into their mouth is very dangerous, one should be careful. A mother told me that her son puts whatever he finds in his mouth: nails, screws whatever; and I reorganized all materials." T3 "music tramboline or even rocking back and forth may be a start for communication. For example I can make similar sounds when they are jumping on a tramboline. Sometimes when behavior such as squeezing oneself in a corner, pressing down on the hands, on materials are intense; I have a difficult time in making them focus on the studies. Problems arise when we try to stop them from doing such behavior; I think that letting them touch first and then continuing with the activity works."

\section{Discussion}

The objective of this study was to determine the sensory differences of children with autism and to examine their effects on the home and school environments. As a conclusion, it has been observed in all children that they have sensory differences in movement, sound, touch, visual and taste and scent areas. Some studies carried out abroad such as the study by Kientz and Dunn (1997) with a study group of 32 families having children with autism between the ages of three-thirteen and 64 families that have a child without autism which has put forth a difference in $85 \%$ of the 
Girli, A. (2016). Examining sensory differences of children with autism in early childhood: Effects of school and home settings. International Journal of Human Sciences, 13(1), 518-531. doi:10.14687/ijhs.v13i1.3520

ninety nine items of the sensory profile form. Again, many studies have determined higher ratios of sensory behavior in 45-95\% of children in the autism spectrum group in comparison with the children in the norm group. (Baker et.al., 2007; Baranek et.al., 2006; Leekam et.al. (2007); Tomcheck and Dunn 2007). Baranek et.al. have determined in their study (2006) carried out on children frim 5-80 months that 69\% have excessive or low sensory reactions levels.

Low sensitivity towards stimuli was observed more in the study group in comparison with over sensitivity. For example, the ratios of behavior that puts forth a low sensitivity towards movement such as "ordering toys" and not using them properly (\%81.82), rocking back and forth (\% 72.73), jumping (\% 68.18) are greater than the percentages of refraining from games involving movement (\% 9.) and being afraid of stairs (4\%) (Leekam et.al.,2007).

The most frequently observed behaviors were putting objects in the mouth $(\% 68,18)$ due to low sensitivity in touch; watching moving objects $(\% 77,27)$ and ordering objects $(\% 72,73)$ due to low sensitivity in seeing; enjoying some music and sounds $(\% 72,73)$ due to low sensitivity in hearing and discovering objects by licking and smelling $(\% 72,73)$ due to low sensitivity in taste and scent. These results are in accordance with the results of various other studies as well as the observations of the family and caregivers. For example, it is stated that low sensitivity in OSB is observed more in comparison with high sensitivity (Rogers \& Ozonoff 2005). It has been determined in another study that adults with Asperger syndrome put forth excessive sensitivity (Blakemore, Tavassoli, Calo, Thomas, Catmur, Frith, et.al., 2006).

It is observed that there are differences in the prevalence of various behaviors in the school and home environments. One of the reasons for these differences may be the difference of the ordering and the materials used in these environments. For example, a student who continuously demands vocal stimuli can find these in a cupboard at school and the frequent use of these stimuli may be less due to the environment. On the contrary, the materials are generally placed in baskets or places that the child may easily reach at home. Another reason may be the difference in the behaviors towards mothers or the instructors. It is a natural difference that the child hugs his/her mother more. Another reason can be the differences in the interpretation of behavior by the parents and instructors. For example, whereas mothers have not observed that a student watches the movement of the shadows of leaves or of his own shadow; this behavior has been observed by the instructors. Or, the behavior of the "improper use of toys" has been stated more by instructors in comparison with the families. Various playing styles have been accepted as "normal" by the mothers and have not been interpreted as an indication of sensory difference.

The qualitative results of the study indicate that behavior of children due to sensory differences have negative effects on the daily routines of the families. It has been put forth those daily routines which are carried out more than once during the day such as eating, self-cleaning, dressing up or removing clothes are sources of stress for the mothers thereby causing them to feel stressed, sad and desperate. Whereas families have stated that they feel ashamed in addition to these other emotions during routines such as going to a restaurant or going to a barber shop. International studies have also put forth that behavior due to sensory differences have negative effects on both the routines inside and outside the house. Families have stated that they need to make arrangements in consideration of the sensory differences of their children when planning the routines of their daily lives, work lives or their leisure times (Schaaf et.al.,2011).

Familial routines such as those of school and work can be problematic when children are not flexible and do not digress from their own routines (Larson, 2006). Some studies have determined more stress and burnout in parents of children with autism in comparison with those who do not have children with disability (Hastings, Kovshoff, Ward, Delgi Espinosa, Brown \& Remington, 2005; Larson, 2006). In addition, it is emphasized that the number of studies focusing on how the sensory behaviors of children with autism affect the families/care givers and roles and the family routines. Individuals with low function ASD may display severely destructive and aggressive behavior due to troubling emotional inputs. The determination of the personal sensory problems that cause this will enable the arrangement of the environment and daily routines thereby 
Girli, A. (2016). Examining sensory differences of children with autism in early childhood: Effects of school and home settings. International Journal of Human Sciences, 13(1), 518-531. doi:10.14687/ijhs.v13i1.3520

decreasing stressful situations. Disliking being touched causes an increase in social problems as well as distress/stress in parents who want to touch their children to show their affection. Thus, parents indicate that they need an explanation regarding the experiences in the worlds of children (Leekam et.al., 2007). The decisiveness provided by the family routines results in the family members feeling more secure with a higher sense of belonging to the family (DeGrace, 2004); determination of the effects of sensory behaviors on the family routines and roles might be helpful to professionals working with families in their studies. Knowing the sensory symptom characteristics of ASD individuals at different levels, different ages and different functionality levels will be helpful in the planning of services towards families as well as estimating the course of the symptoms (Ben-Sasson, et.al., 2008).

It has been observed that the observations of instructors and the arrangements made for the sensory differences have not made any negative effects on the training process of the children. For example, the expression of instructor T3 "I have a student in my group who is sensitive to touch, and one does not like movement a lot. The one who is sensitive to touch wants to hold hands and rock back and forth like a fisherman but the other does not want to hold ands and just rock back and forth. I first made them hold plastic rings that they like holding and move slowly; now they like the game," or that of psychologist T3 "My student sometimes when behavior such as squeezing oneself in a corner, pressing down on the hands, on materials are intense; I have a difficult time in making them focus on the studies. Problems arise when we try to stop them from doing such behavior; I think that letting them touch first and then continuing with the activity works," shows that instructors can provide solutions even if they face difficulties from time to time. It can be stated that the knowledge of the instructors who participated in the study on sensory differences and the things that might be done in the education environment have prevented any negativities that might arise. The fact that the education environment can be structured more easily and that the time spent at school is limited provides advantages to the instructors. There are studies in literature for applying intervention programs using methods such as training sessions for sensory integration, visual clues, educational strategies, social stories (Dunn et.al.,, 2002b; Dunn, 2007; Schaaf et.al., 2011). In Turkey, Özlü-Fazlıŏglu (2004), Özlü-Fazlığlu and Baran (2004) and Ersöz (2006) have carried out studies to determine the sensory differences after which they have applied a training program to decrease this behavior and have been successful in doing so.

\section{Limitations and suggestions}

This study has provided important information since as the first study carried out in Turkey that examines the effects of the sensory differences of children in the OSB group on their school and home environments. However, the effects on and problems caused in the home environment are limited with the families of 22 children whereas those in the education environment are limited with 8 trainers; hence the results should be interpreted by taking into account these limitations. It is observed when a literature survey is made that the detailed evaluation of the sensory problems of clinicians by experts will ease the understanding of the experiences of many people with autism and help them (Leekam et.al., 2007). The number of studies in literature showing that the sensory differences of individuals with OSB are greater than their normally developing peers is very high. However, it is stated that further studies are required for the prevalence of sensory differences in the OSB sub-types as well as their types and symptoms (Ben-Sasson, et.al., 2008).

It can be suggested for further studies in our country to a. examine the sensory differences of children with autism at different ages and in a larger sample group b. examination of the loads brought upon to the school and family life by these properties and c. the development of programs that will pave the way for various arrangements and guidance for families. 
Girli, A. (2016). Examining sensory differences of children with autism in early childhood: Effects of school and home settings. International Journal of Human Sciences, 13(1), 518-531. doi:10.14687/ijhs.v13i1.3520

\section{References}

American Psychiatric Association, (2000). "Diagnostic and statistical manual of mental disorders (4th ed. DSM-IV-TR).” Washington, DC: American Psychiatric Association.

Ashburner, J., Ziviani, J., \& Rodger, S. (2008) 'Sensory Processing and Classroom Emotional, Behavioral, and Educational Outcomes in Children with Autism Spectrum Disorder', American Journal of Occupational Therapy 62(5) 564-573. doi: 10.5014/ajot.62.5.564.

View Article: DOI: http://dx.doi.org/10.5014/ajot.62.5.564

Baker, A. E., Lane, A., Angley, M. T., \& Young, R. L. (2007). The relationship between sensory processing patterns and behavioral responsiveness in autistic disorder: A pilot study. Journal of Autism and Developmental Disorders 38(5) 867-875. doi: 10.1007/s10803-007-0459-0.

View Article: DOI: http://dx.doi.org/10.1007/s10803-007-0459-0

Baranek, G. T., David, F. J., Poe, M. D., Stone, W. L., \& Watson, L. R. (2006). Sensory experience questionnaire: Discriminating sensory features in young children with autism, developmental delays, and typical development. Journal of Child Psychology and Psychiatry, 47(6), 591-601. doi: 10.1111/j.1469-7610.2005.01546.x

View Article: DOI: http://dx.doi.org/10.1111/j.1469-7610.2005.01546.x

Baranek, G.T. (2002). Efficacy of Sensory and Motor Interventions for Children with Autism. Journal of Autism and Developmental Disorders 32(5) 397-422. doi: 10.1023/A:1020541906063

View Article: DOI: http://dx.doi.org/10.1023/A:1020541906063

Ben-Sasson, A., Hen, L., Fluss, R. Cermak, S. A., Engel-Yeger, B. \& Gal, E. (2008). A MetaAnalysis of Sensory Modulation Symptoms in Individuals with Autism Spectrum Disorders. Journal of Autism and Developmental Disorders, 39, 1-11.doi: 10.1007/s10803-008-0593-3

View Article: DOI: http://dx.doi.org/10.1007/s10803-008-0593-3

Blakemore, S. J., Tavassoli, T., Calo`, S., Thomas, R. M., Catmur, C., Frith, U., et al. (2006). Tactile sensitivity in Asperger syndrome. Brain and Cognition, 61(1), 5-13. doi:10.1016/j.bandc.2005.12.013

View Article: DOI: http://dx.doi.org/10.1016/j.bandc.2005.12.013

Büyüköztürk, Ş. (2003). Veri analiz̨i el kitabı. 3. Baskı., Pegem A Yayınlanı, 195 s., Ankara.

Case-Smith, J. \& Miller, H. (1999): Commentary: Interventions to Facilitate Auditory, Visual and Motor Integration Show Me the Date. Journal of Autism and Developmental Disorders, 30(5): 423-425. doi: 10.1023/A:1005587104093

View Article: DOI: http://dx.doi.org/10.1023/A:1005587104093

Dawson, G., \& Watling, R. (2000). Interventions to facilitate auditory, visual, and motor integration in autism: A review of the evidence. Journal of Autism and Developmental Disorders, 30, 415421. doi: 10.1023/A:1005547422749

View Article: DOI: http://dx.doi.org/10.1023/A:1005547422749

DeGrace, B.W. (2004) 'The Everyday Occupation of Families with Children with Autism', American Journal of Occupational Therapy 58(5): 543-550. doi: 10.5014/ajot.58.5.543

View Article: DOI: http://dx.doi.org/ 10.5014/ajot.58.5.543

Dunn, W. (1997). The Impact of Sensory Processing Abilities on the Daily Lives of Young Children and Their Families: A Conceptual Model. Infants and Young Children. 9(4):23-35.

View Article: http://journals.lww.com/iycjournal/ Abstract/1997/ 04000/The_ Impact_ of _ Sensory_Processing_Abilities_on_the.5. aspx

Dunn, W. (2007). Supporting children to participate successfully in everyday life by using sensory processing knowledge. Infants and Young Children, 20, 84-101. doi: 10.1097/01.IYC.0000264477.05076.5d

View Article: DOI: http://dx.doi.org/ 10.1097/01.IYC.0000264477.05076.5d

Dunn, W., Myles, B. S., \& Orr, S. (2002a). Sensory processing issues associated with Asperger syndrome: A preliminary investigation. American Journal of Occupational Therapy, 56, 97-102. doi: 10.5014/ajot.56.1.97 
Girli, A. (2016). Examining sensory differences of children with autism in early childhood: Effects of school and home settings. International Journal of Human Sciences, 13(1), 518-531. doi:10.14687/ijhs.v13i1.3520

View Article: DOI: http://dx.doi.org/ 10.5014/ajot.56.1.97

Dunn, W., Saiter, J., \& Rinner, L. (2002b). Asperger syndrome and sensory processing: A conceptual model and guidance for intervention planning. Focus on Autism and Other Developmental Disabilities, 17(3), 172-185. doi: 10.1177/10883576020170030701

View Article: DOI: http://dx.doi.org/ 10.1177/10883576020170030701

Ersöz Ünal, A. (2006). Sanat Eğitiminin Otizmli Cocuklarn Duyusal Problemleri Üzerine Etkisinin Incelenmesi. Yayınlanmamış Yüksek Lisans Tezi, Trakya Üniversitesi Sosyal Bilimler Enstitüsü.

Özlü-Fazlığlu, Y. (2004). Duyusal entegrasyon programınm otižmli çocuklarm duyusal ve davramıs problemleri üzerine etkisinin incelenmesi. Yayımlanmamıs Doktora Tezi, Ankara Üniveristesi, Fen Bilimleri Enstitüsü.

Özlü-Fazlıoglu, Y. \& Baran, G. (2004): Duyusal Entegrasyon Programmn Duyusal ve Davranış Problemleri Üzerine Etkisinin Incelenmesi, Ankara: AnkaraÜniversitesi Basımevi

Hastings, R.P., Kovshoff, H.,Ward, N.J., Delgi Espinosa, F., Brown,T. \& Remington, B. (2005) 'Systems Analysis of Stress and Positive Perceptions in Mothers and Fathers of Pre-School Children with Autism', Journal of Autism and Developmental Disorders 35(5): 635-644. doi: 10.1007/s10803-005-0007-8

View Article: DOI: http://dx.doi.org/ 10.1007/s10803-005-0007-8

Grandin, T. (1995). Thinking in pictures and other reports from my life with autism. NY: Vintage Books.

Green,V.A., Pituch, K.A., Itchon, J., Choi, A., O’Reilly, M. \& Sigafoos, J. (2006) 'Internet Survey of Treatments Used by Parents of Children with Autism', Research in Developmental Disabilities 27(1): 70-84. doi:10.1016/j.ridd.2004.12.002

View Article: DOI: http://dx.doi.org/ 10.1016/j.ridd.2004.12.002

Kanner, L. (1943). Autistic disturbances of affective contact. Nervous Child, 2, 217-50.

Klintwall L., Holm A, Eriksson M, Carlsson LH, Olsson MB, Hedvall A, Gillberg C, Fernell E.. (2011). Sensory abnormalities in autism: A brief report. Research in Developmental Disabilities, 32(2), 795-800. doi:10.1016/j.ridd.2010.10.021

View Article: DOI: http://dx.doi.org/10.1016/j.ridd.2010.10.021

Kurcaali-İftar,G. \& Tekin-İftar, E. (1997). Tek Denekli Araștırma Yöntemleri. Ankara: Türk Psikologlar Derneği Yayınları.

Kientz, M. A., \& Dunn, W. (1997). A comparison of the performance of children with and without autism on the Sensory Profile. American Journal of Occupational Therapy, 51(7), 530-537. doi: 10.5014/ajot.51.7.530

View Article: DOI: http://dx.doi.org/ 10.5014/ajot.51.7.530

Korkmaz, B. (2003). Asperger sendromu. İstanbul : Adam Yayıncilik.

Larson, E. (2006). 'Caregiving and Autism: How Does Children's Propensity of Routineization Influence Participation in Family Activities?' Occupation, Participation, and Health, 26(2): 6979. doi: $10.1177 / 153944920602600205$

View Article: DOI: http://dx.doi.org/ 10.1177/153944920602600205

Leekam, S.R., Nieto, C., Libby, Wing, L., Gould, C. (2007). Describing the sensory abnormalities of children and adults with autism. Journal of Autism and Developmental Disorders, 37(5), 894 910. doi: 10.1007/s10803-006-0218-7

View Article: DOI: http://dx.doi.org/ 10.1007/s10803-006-0218-7

Mandell, D.S., Novak, M.M. \& Levy, S. (2005). Frequency and correlates of treatment use among a community sample of children with autism (presentation). Proceedings of the 4th International Meeting for Autism Research, San Diego, CA.

McConachie, H. R. and Moore, V. (1994). Early expressive language of severely visually impaired children. Developmental Medicine \& Child Neurology, 34(3); 230-239. doi: 10.1111/j.14698749.1994.tb11836.x

View Article: DOI: http://dx.doi.org/ 10.1111/j.1469-8749.1994.tb11836.x 
Girli, A. (2016). Examining sensory differences of children with autism in early childhood: Effects of school and home settings. International Journal of Human Sciences, 13(1), 518-531. doi:10.14687/ijhs.v13i1.3520

Militerni R., Bravaccio C., Falco C., Fico C. and Palermo M. T. (2002). Repetitive behaviors in autistic disorder. Eur Child Adolesc Psychiatry, 11(5): 210-218. doi: 10.1007/s00787-002-0279$\mathrm{x}$

View Article: DOI: http://dx.doi.org/ 10.1007/s00787-002-0279-x

Minshew, N. J., \& Hobson, J. A. (2008). Sensory sensitivities and performance on sensory perceptual tasks in high-functioning individuals with autism. Journal of Autism and Developmental Disorders, 38(8), 1485-1498. doi: 10.1007/s10803-007-0528-4

View Article: DOI: http://dx.doi.org/ 10.1007/s10803-007-0528-4

Rogers, S. J., Hepburn, S., \& Wehner, E. (2003). Parent reports of sensory symptoms in toddlers with autism and those with other developmental disorders. Journal of Autism and Developmental Disorders, 33(6), 631-642. doi: 10.1023/B:JADD.0000006000.38991.a7

View Article: DOI: http://dx.doi.org/ 10.1023/B:JADD.0000006000.38991.a7

Rogers, S. J., \& Ozonoff, S. (2005). Annotation: What do we know about sensory dysfunction in autism? A critical review of the empirical evidence. Journal of Child Psychology and Psychiatry, 46, 1255-1268. doi: 10.1111/j.1469-7610.2005.01431.x

View Article: DOI: http://dx.doi.org/ 10.1111/j.1469-7610.2005.01431.x

Smith Myles, B., Tapscott Cook, K., Miller, N., Rinner, L., \& Robbins, L., (2000). Asperger Syndrome and sensory issues. Practical solutions for making sense of the world. Shawnee Mission, KS: Autism, Asperger Publishing Company.

Schaaf RC, Toth-Cohen S, Johnson SL, Outten G, Benevides TW. (2011). The everyday routines of families of children with autism: examining the impact of sensory processing difficulties on the family. Autism, 15(3):373-89. doi: 10.1177/1362361310386505.

View Article: DOI: http://dx.doi.org/ 10.1177/1362361310386505

Sussman, F. (1999). More than words. Canada: Beacon Herald Press.

Talay-Ongan, A. \& Wood, K. (2000). Unusual Sensory Sensitivities in Autism: a possible crossroads. International Journal of Disability, Development and Education, Vol. 47(2), 201-212. doi: $10.1080 / 713671112$

View Article: DOI: http://dx.doi.org/ 10.1080/713671112

Toper-Korkmaz, Ö. \& Diken, İ. (2010). Stereotipik Davranışların Azaltılmasında Kullanılan Yöntemlerin Etkililiği: Betimsel ve Meta Analizi, Özel Eğitim Dergisi, 11(2), 1-12. doi: 10.1501/Ozlegt_0000000149

View Article: DOI: http://dx.doi.org/ 10.1501/Ozlegt_0000000149

Tomchek, S.D. \& Dunn, W. (2007). 'Sensory Processing in Children with and without Autism: A Comparative Study Using the Short Sensory Profile', The American Journal of Occupational Therapy 61(2): 190-200. doi: 10.5014/ajot.61.2.190

View Article: DOI: http://dx.doi.org/ 10.5014/ajot.61.2.190

Wainwright, J. A., \& Bryson, S. E. (1996). Visual-spatial orienting in autism. Journal of Autism and Developmental Disorders, 26,423-438. doi: 10.1007/BF02172827

View Article: DOI: http://dx.doi.org/ 10.1007/BF02172827

Yıldırım, A. \& Şimşek, H. (2000). Sosyal Bilimlerde Nitel Araştırma Yöntemleri. Ankara: Seçkin Yayınları. 